\title{
Összefoglaló az ESC 2020-as pitvarfibrilláló betegek ellátására vonatkozó irányelveiröl
}

\author{
Salló Zoltán¹, Kupó Péter², Szegedi Nándor', Csanádi Zoltán, Duray Gábor, \\ Kardos Attila ${ }^{5}$, Sághy László ${ }^{6}$, Simor Tamás², Tahin Tamás 1, 7, Zima Endre', \\ Merkely Béla', Gellér László
}

\author{
${ }^{1}$ Semmelweis Egyetem, Városmajori Szív- és Érgyógyászati Klinika, Budapest \\ ²Pécsi Tudományegyetem, Szívgyógyászati Klinika, Pécs \\ ${ }^{3}$ Debreceni Egyetem Klinikai Központ Kardiológiai és Szívsebészeti Klinika, Debrecen \\ ${ }^{4}$ Magyar Honvédség Egészségügyi Központ, Budapest \\ ${ }^{5}$ Gottsegen György Országos Kardiovaszkuláris Intézet, Budapest \\ ${ }^{6}$ Szegedi Tudományegyetem Klinikai Központ II. sz. Belgyógyászati Klinika és Kardiológiai Központ, Szeged \\ 'Zala Megyei Szt. Rafael Kórház, Zalaegerszeg
}

Levelezési cím:

Prof. dr. Gellér László, PhD, Semmelweis Egyetem, Városmajori Szív- és Érgyógyászati Klinika, Budapest

1122 Budapest, Városmajor u. 68. E-mail: laszlo.geller@gmail.com

\section{Bevezetés}

A leggyakoribb tartós ritmuszavar, a pitvarfibrilláció (PF) prevalenciája a $4 \%$-ot is elérheti a 20 évnél idösebb populációban. A PF emeli a halálozás, a szívelégtelenség, a depresszió és a demencia kialakulásának a kockázatát, rontja az életminőséget, így mindezek által jelentős terhet ró a betegekre, orvosokra és az egészségügyi rendszerre egyaránt. Jelen közlemény az Európai Kardiológus Társaság (ESC) 2020-ban publikált irányelveit foglalja össze a PF ellátására vonatkozóan (1).

\section{Definíció és diagnosztika}

A PF definíció szerint olyan supraventricularis tachyarrhytmia, ahol a koordinálatlan pitvari elektromos aktiváció ineffektív pitvari kontrakciókat eredményez. A PF diagnózisának felállítása standard 12 elvezetéses EKG-felvétellel, vagy legalább 30 másodpercet elérő minimum egy elvezetéses EKG-regisztrátummal lehetséges. A PF jellegzetes EKG-eltérései közé az ir- regulárisan irreguláris $\mathrm{R}-\mathrm{R}$-intervallumok, az ismétlődő P-hullámok hiánya és az irreguláris pitvari aktivációt jelző f-hullámok tartoznak.

A szívbe ültetett kardiális implantálható elektromos eszközök (CIED) elterjedésével elérhetővé vált úgynevezett magas frekvenciájú pitvari epizódok (AHRE) diagnosztizálása is. Ezen eszközök növekvő elérhetőségével különösen fontossá vált a korrekt nevezéktan használata az AHRE és PF megkülönböztetésére, hiszen lényeges különbségek vannak a két betegcsoport terápiáját illetően. Klinikai PF diagnózisa a fentebb jelzett EKG-regisztrátummal állítható fel. Amennyiben CIED-del AHRE-t regisztráltunk és nem áll rendelkezésre PF-et igazoló EKG-regisztrátum, úgy a szubklinikai PF diagnózisát kell felállítanunk (1. ábra).

\section{Klinikai jellemző"k}

A PF tünetei széles skálán mozoghatnak. A betegek egy részében a ritmuszavar tünetmentes marad. A tünetes betegeknél leggyakrabban palpitációs panaszok, dyspnoe, fáradság, csökkent fizikai terhelhetőség je- 
Nincsenek PF-nek tulajdonítható tünetek, és NEM diagnosztizáltak korábban klinikai PF-t

\section{Orvos által igazolt: \\ - CIED által rögzített elektrogramok,} amelyeken AHRE látható
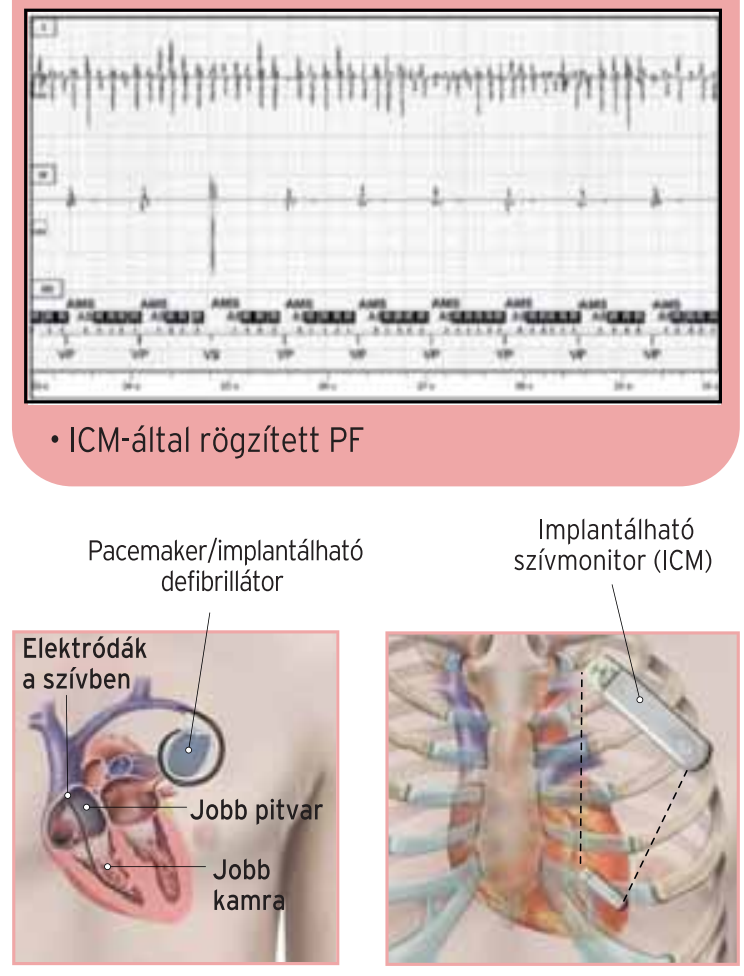

Implantálható szívmonitor (ICM)

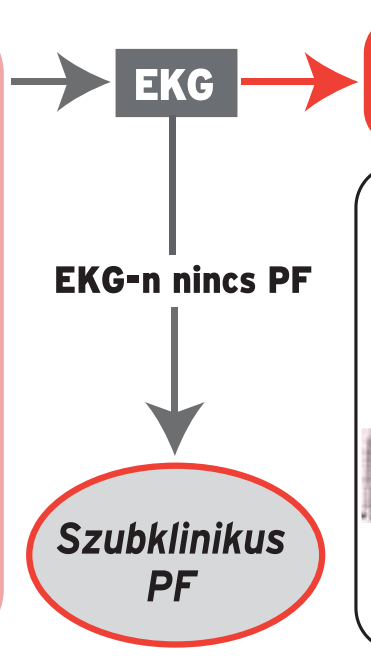

\section{EKG-n PF látható (orvos által igazolt)}

- Teljes 12 elvezetéses EKG, vagy

- egy EKG ritmuscsík $\geq 30$ sec-os PF epizóddal (hordozható EKG-készülék által rögzített EKG-k is)
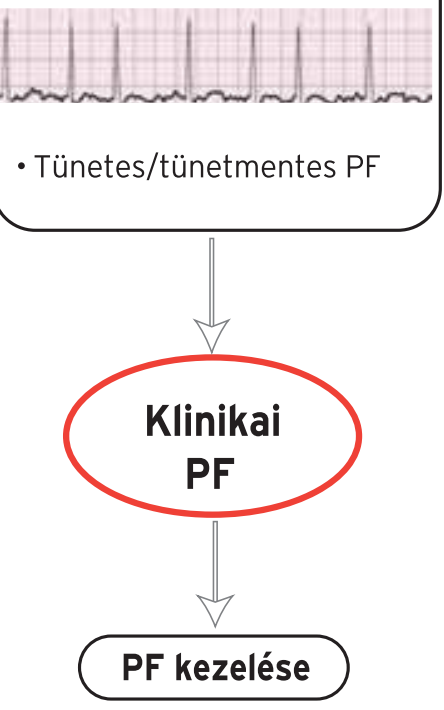

1. ÁBRA. A pitvari magas frekvenciájú epizódok (AHRE)/szubklinikus pitvarfibrilláció diagnosztikája (AHRE: pitvari magas frekvenciájú epizód; CIED: kardiális implantálható elektromos eszköz; EKG: elektrokardiogram; ICM: implantálható szívmonitor; PF: pitvarfibrilláció)

lentkezik, de előfordulhat mellkasi fájdalom, szédülés, syncope és alvászavar is. Ritkán hemodinamikai instabilitást is okozhat, ekkor syncope, súlyos hipotenzió, akut szívelégtelenség, folyamatos szívizom-iszkémia és akár kardiogén sokk is felléphet.

\section{A PF típusai, PF-burden és progresszió}

A PF-epizódok jelentkezése, időtartama és spontán terminálódása alapján hagyományosan öt típust különböztetnek meg. A praktikus felosztás ellenére a besorolásnak jelentős korlátai vannak, mivel a PF kezelésére vonatkozó ajánlások nem kizárólag a PF időbeliségén alapulnak. A PF-betegek jellemzésére a terápiás döntések átláthatósága és megkönnyítése érdekében a 2020-as ESC PF-irányelvek bevezetik az úgynevezett 4S-PF-rendszert, amellyel egyszerűen jellemezhető a stroke-rizikó, a betegség és a betegség hátterében álló szubsztrát súlyossága, a tünetek mértéke és a PF időbelisége is (2. ábra).

\section{Terápia - az ABC-útvonal}

A hosszú távú kimenetel javítása érdekében a pitvarfibrilláló betegek menedzsmentje holisztikus szemléletet kíván az egészségügyi rendszer minden szintjén és a különféle szakterületek között is: ez az úgynevezett $\mathrm{ABC}$-útvonal.

\section{${ }_{g} A^{y \prime}$ - antikoaguláció/stroke-megelőzés}

A PF-hez társuló stroke-rizikó specifikus kockázati tényezők jelenlététől függ. A gyakori kockázati tényezőket a $\mathrm{CHA}_{2} \mathrm{DS}_{2}$-VASc-pontrendszer foglalja össze (1. táblázat). Antitrombotikus kezelés megkezdése előtt fel kell 


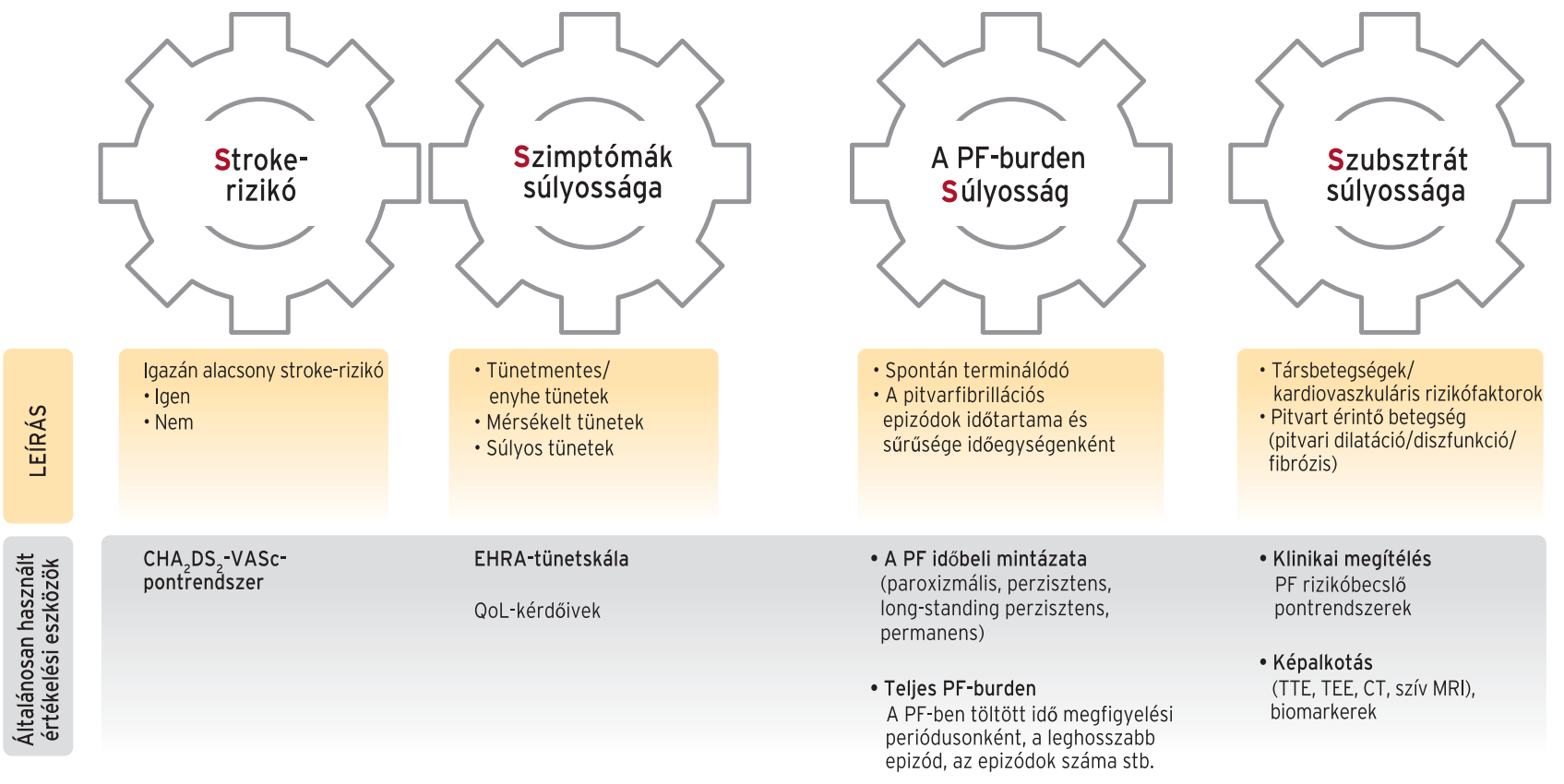

2. ÁBRA. A 4S-PF-rendszer (BP: bal pitvar; CT: komputertomográfia; MRI: mágnesesrezonancia-képalkotás; PF: pitvarfibrilláció; QoL: életminőség; TEE: nyelöcsövön keresztül végzett szívultrahang-vizsgálat; TTE: mellkason keresztül végzett szívultrahang-vizsgálat)

mérni a vérzés lehetséges kockázatát. Vérzéses rizikó meghatározására leggyakrabban a HAS-BLED-pontrendszer használatos (2. táblázat). A vérzéses rizikó befolyásolható és nem befolyásolható kockázati tényezőkből tevődik össze. Kiemelten fontos az antikoagulált betegek esetében a módosítható, vérzéses rizikót emelő faktorok azonosítása és lehetőség szerinti kezelése

\section{TÁBLÁZAT. $C H A_{2} D S_{2}$-VASc pontrendszer}

\section{Kockázati tényezők és definíciójuk}

C Pangásos szívelégtelenség

A szívelégtelenség jelei/tünetei vagy

a csökkent bal kamrai ejekciós frakció ob-

jektív jelei; vagy hipertrófiás cardiomypathia

H Hipertónia vagy antihipertenzív terápia

1

A 75 év vagy afeletti életkor

D Diabetes mellitus

Éhomi glükóz > $125 \mathrm{mg} / \mathrm{dl}$ ( $7 \mathrm{mmol} / \mathrm{l})$ vagy

orális antidiabetikummal vagy inzulinnal

folytatott kezelés

S Korábban lezajlott stroke, tranziens iszkémiás attak vagy tromboembólia

\section{V Érbetegségek}

Angiográfiailag szignifikás CAD, korábban

lezajlott MI, PAD vagy plakkok az aorta falán

A 65-74 év közötti életkor

Sc Nem (női nem)

Pontszám

\section{Maximum pont}

$C A D=$ koszorúér-betegség; $M I=$ miokardiális infarktus; $P A D=$ perifériás verőérbetegség.
2. TÁBLÁZAT. Vérzéses rizikót növelő tényezők a HAS-BLED-pontrendszer szerint

Kockázati tényezők és definíciójuk

Pont-

szám

H Nem kontrollált hipertenzió SBP $>160$ Hgmm

A Csökkent vese- és/vagy májfunkció Dialízis, transzplantáció, szérumkreatinin $>200 \mu \mathrm{mol} / \mathrm{I}$, cirrhosis, bilirubin >×2 ULN, AST/ ALT/ALP $>\times 3$ ULN

S Stroke

Korábbi iszkémiás vagy vérzéses ${ }^{a}$ stroke

$B$ Anamnézisben vérzés vagy arra hajlamosító tényezó

Korábbi major vérzés vagy anémia vagy súlyos thrombocytopenia

L Ingadozó INR TTR $<60 \%$

E Időskor $>65$ év vagy extrém fragilitás

D Drog- vagy túlzott alkoholfogyasztás Thrombocytaaggregáció-gátlók vagy nem szteroid gyulladáscsökkentők egyidejü alkalma- ként zása; és/vagy túlzott ${ }^{c}$ alkoholfogyasztás

\section{Maximum pont}

ALP: alkalikus foszfatáz; ALT: alanin-aminotranszferáz; AST: aszpartát-aminotranszferáz; BP: vérnyomás; INR: international normalized ratio;

TTR: terápiás tartományban eltöltött idő; ULN: a normálérték felső határa; VKA: K-vitamin-antagonista

“A vérzéses stroke a "B" kritérium alapján is 1 pontot ér;

'VKA-kezelésben részesülő betegek számára;

'A túlzott alkoholfogyasztás (pl. >14 alkoholegység hetente) abban az esetben tényezö, amennyiben a klinikus úgy ítéli meg, hogy ez hatással van az egészségre, vagy növeli a vérzés kockázatát 


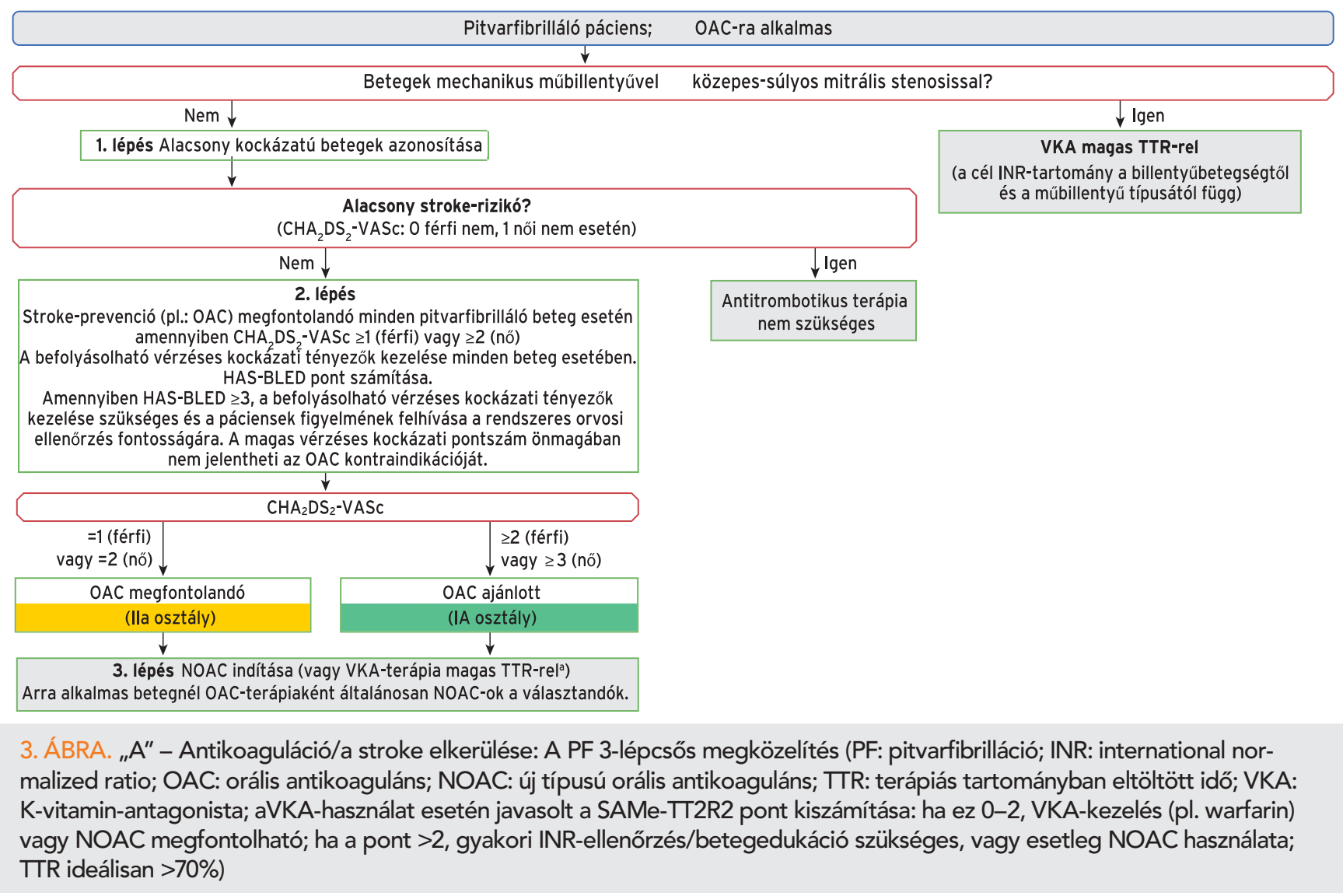

a klinikai kimenetel javítása érdekében. Önmagában a magas vérzéses rizikó nem lehet oka az orális antikoaguláns (OAC) kezelés leállításának.

$\mathrm{CHA}_{2} \mathrm{DS}_{2}$-VASc-pontrendszer alkalmazása javasolt a stroke-rizikó meghatározására, így azonosíthatók azon alacsony kockázatú betegek, akiknél antitrombotikus terápia nem indikált. Az OAC indikációval rendelkező betegek esetén (kivéve a mechanikus szívbillentyűvel élö, vagy közepes-súlyos mitralis stenosisban szenvedő betegeket) az új típusú, direkt hatásmechanizmusú orális antikoagulánsok (NOAC) előnyben részesítendők a K-vitamin-antagonistákkal (KVA) szemben (3. ábra).

\section{„B" - hatékonyabb tünetkezelés}

\section{Frekvenciakontroll-terápia}

A farmakológiai frekvenciakontroll számos gyógyszerrel elérhető (béta-blokkolók, non-dihidropiridin típusú kalciumcsatorna-blokkolók, digoxin), a gyógyszerek megválasztásakor szükséges a fennálló társbetegségek figyelembe vétele. Az optimális célfrekvencia még mindig nem teljesen tisztázott. A gyógyszeres kezelés sikertelensége esetén, végső megoldásként AV-csomó-abláció jön szóba. Amenynyiben a betegnél az előzőekben taglaltak ellentéte, azaz bradycard PF áll fenn, pacemakerkezelés válhat szükségessé.

\section{Ritmuskontroll-terápia}

A ritmuskontroll magába foglalja a sinusritmus helyreállítására és fenntartására tett terápiás kísérleteket, amelybe beletartozik az elektromos kardioverzió (ECV), az antiaritmiás szerek (AAD) alkalmazása és a katéteres abláció is - a megfelelő antikoaguláció és frekvenciakontroll mellett. A ritmuskontroll-terápia elsődleges indikációja a PF okozta tünetek csökkentése és az életminőség javítása.

Kardioverzió: hemodinamikailag instabil PF-betegeknél sürgősségi ECV választandó, míg stabil betegeknél AAD-vel történő farmakológiai kardioverzió és ECV egyaránt megkísérelhető. Strukturális és/vagy iszkémiás szívbetegség fennállta esetén amiodaron javasolt PF farmakológiai kardioverziójára. Újonnan felismert PF kardioverziójára - kontraindikációk hiányában - iv. vernakalant, flecainid, vagy propafenon alkalmazása javasolt. A több mint 48 órája pitvarfibrilláló, hemodinamikailag stabil betegek esetén legalább 3 hét terápiás antikoagulálás, vagy transoesophagealis echokardiográfiás vizsgálattal igazolt bal pitvari fülcsethrombus hiánya szükséges a kardioverzió megkísérléséhez. Kardioverziót követően még az alacsony stroke-rizikójú betegek antikoagulálása is ajánlott 4 héten keresztül. PF-katéterabláció: a PF-katéterablációval a PF-rekurrencia hatékonyan előzhető meg. Megfelelően képzett operatőrök esetén a katéterabláció biztonságos és szuperior az AAD-vel szemben a sinusritmus meg- 


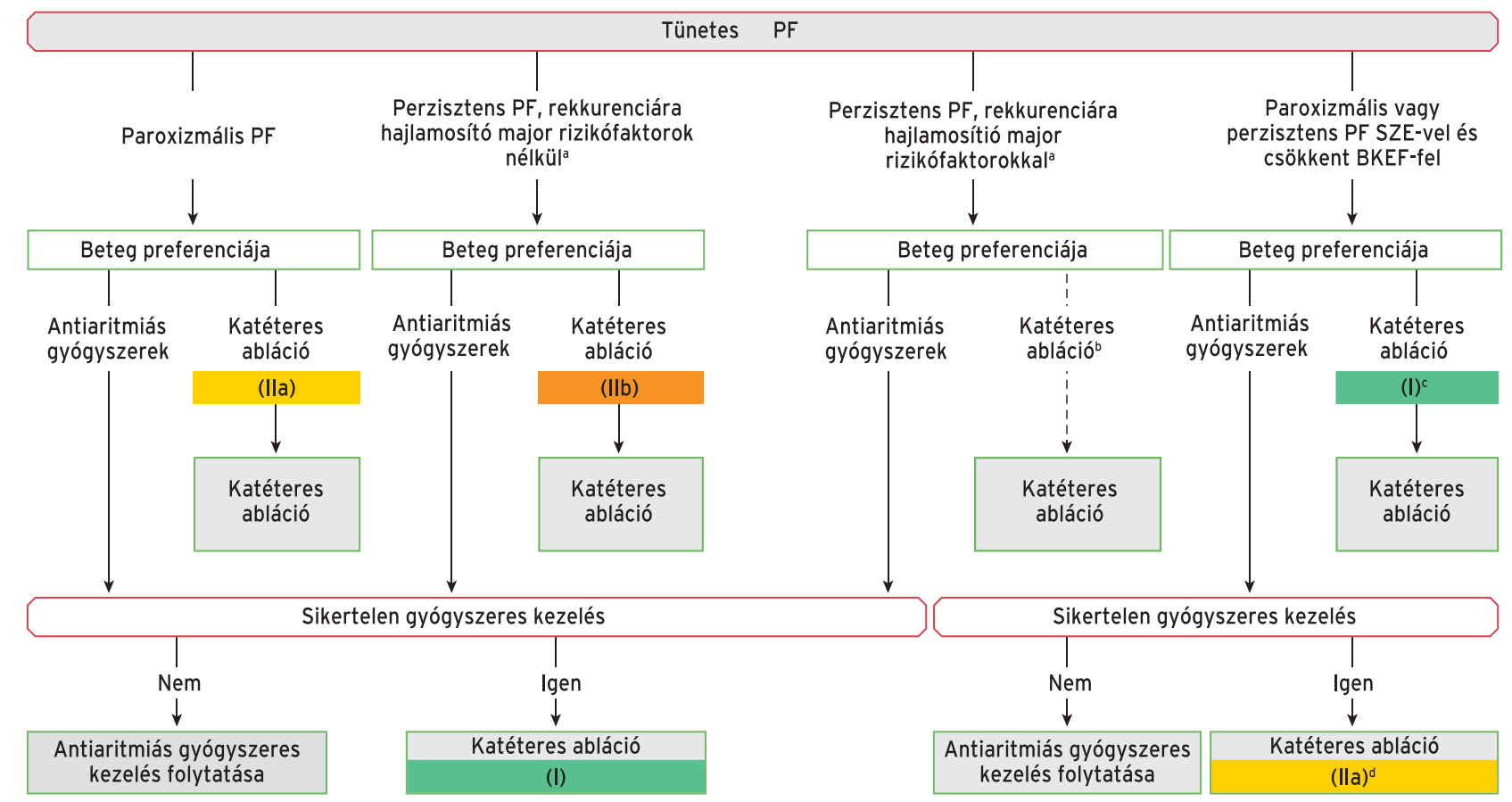

4. ÁBRA. A tünetes pitvarfibrilláció katéteres ablációjára vonatkozó ajánlások (PF: pitvarfibrilláció; BKEF: bal kamrai ejekciós frakció; SZE: szívelégtelenség; a Jelentősen tágult BP, előrehaladott életkor, hosszan fennáló PF, csökkent vesefunkció, egyéb más kardiovaszkuláris rizikófaktorok fennállása. 'Bizonyos körülmények között a katéteres abláció elsővonalbeli kezelés is lehet.)

őrzését és a PF okozta tünetek csökkentését tekintve. Mivel ezidáig nem igazolt a katéterabláció összhalálozást, stroke-ot, vagy súlyos vérzést szignifikánsan csökkentő hatása a megtartott bal kamrai ejekciós frakciójú betegpopulációban, az eljárás általánosan továbbra is tünetes betegekben indokolt az életminőség javítása céljából. A PF katéterablációjának goldstandard eljárása a pulmonalis vénák antrális cirkuláris izolálációja akár pontról pontra (point-by-point) történő rádiófrekvenciás ablációval, akár úgynevezett single-shot ablációs eszközökkel. A katéterablációra vonatkozó ajánlásokat a 4. ábrán tüntettük fel (4. ábra).

\section{Hosszú távú $A A D$-kezelés}

Az AAD-kezelés a PF okozta tünetek csökkentését célozza. A kezelés megkezdése előtt fontos mérlegelni a panaszok súlyosságát, a lehetséges mellékhatásokat és a betegek preferenciáit is. A ritmuskontroll céljából alkalmazott AAD-t elsősorban a biztonságosság, nem pedig a hatékonyság alapján kell megválasztani. A gyógyszerválasztást jelentősen befolyásolják a beteg társbetegségei (5. ábra).

\section{"C" - a rizikótényezők és a társuló kardiovaszkuláris betegségek felismerése és kezelése}

A kardiovaszkuláris rizikófaktorok és a fennálló társbetegségek, beleértve az életmódbeli tényezőket, jelen- tősen befolyásolják a PF kialakulásának kockázatát. Az ABC szemlélet „C" komponense magában foglalja az egyidejüleg előforduló betegségek, a kardiometabolikus kockázati tényezők és az egészségtelen életmódbeli tényezők kezelését. A rizikófaktorok és a szív- és érrendszeri betegségek kezelése segít a stroke megelőzésében, valamint csökkenti a PF-burdent és mérsékli a tüneteket. Elsőosztályú ajánlásként javasolt a hipertóniás betegek PF irányú opportunista szürése, továbbá a pitvarfibrilláló betegek antihipertenzív kezelésének optimalizálása is.

\section{Epidemiológia, klinikai vonatkozások és a magas frekvenciájú pitvari epizódok (AHRE)/szublklinikus PF kezelése}

A CIED-implantáción átesett betegeknél az AHRE/ szubklinikus PF előfordulása $30-70 \%$, de az átlagpopulációban ennél alacsonyabb is lehet. A nagyon rövid epizódok ( $\leq 10-20$ másodperc/nap) klinikailag irrelevánsnak tartandók, mivel nem hozhatók öszszefüggésbe a stroke, vagy tüneteket okozó szisztémás embolizáció emelkedett kockázatával. A hoszszabb AHRE/szubklinikus PF (minimum 5-6 perc) azonban a klinikai PF, az iszkémiás stroke, a major kardiovaszkuláris események és a kardiovaszkuláris mortalitás fokozott rizikójával társul. Habár a rendelkezésre álló bizonyítékok nem elegendők az AHRE/ 


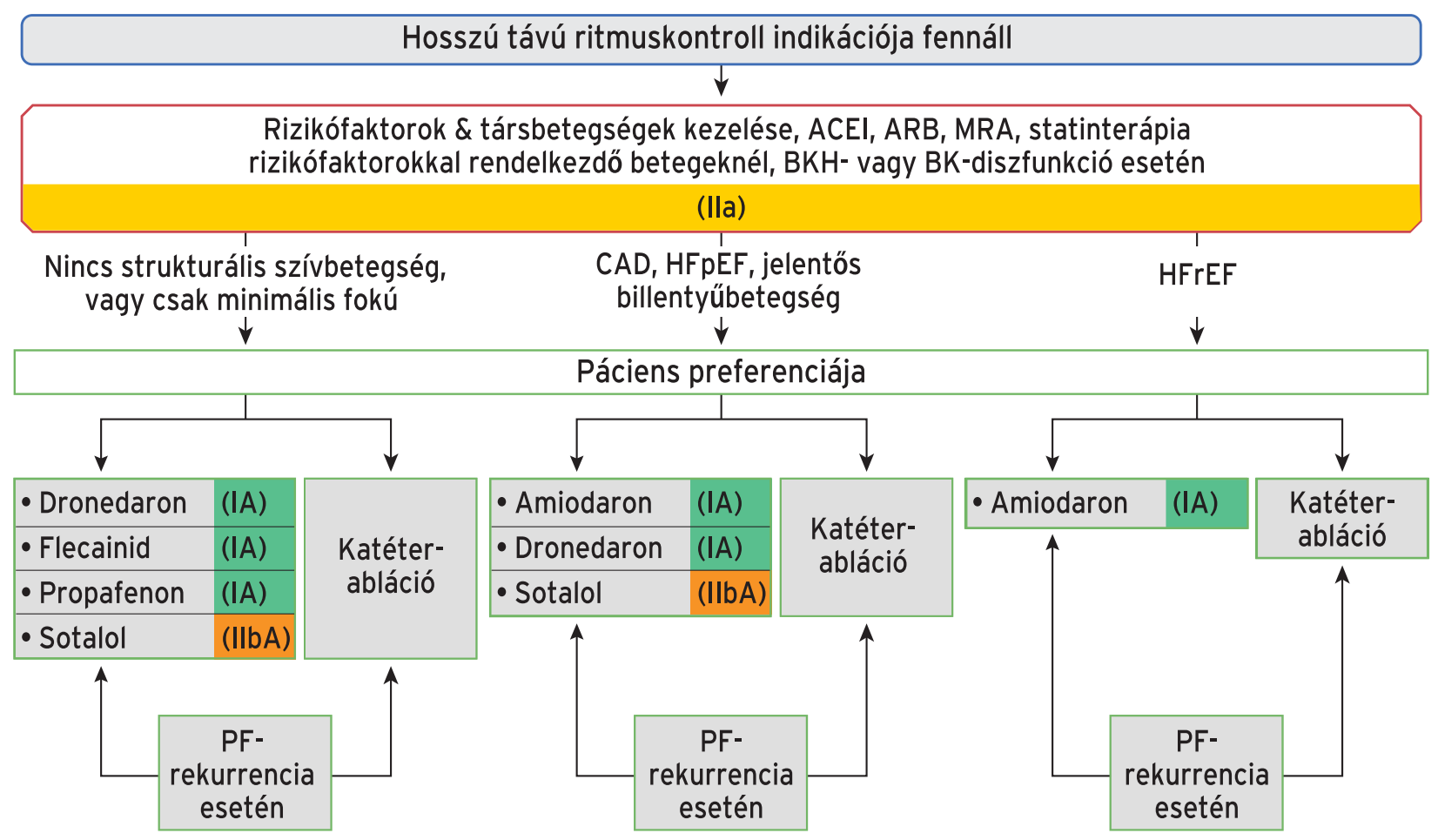

5. ÁBRA. Hosszú távú ritmuskontroll (ACEi: angiotenzinkonvertáló-enzim-inhibitor; PF: pitvarfibrilláció; ARB: angiotenzinreceptor-blokkoló; CAD: koszorúér-betegség; HFpEF: megtartott ejekciós frakciójú szívelégtelenség; HFrEF: szívelégtelenség csökkent ejekciós frakcióval; BK: bal kamra; BKH: balkamra-hipertrófia; MRA: mineralokortikoid-receptor-antagonista)

szubklinikus PF-ben szenvedő betegeknél a rutinszerü OAC-használathoz, a befolyásolható stroke-kockázati tényezőket minden esetben kezelni szükséget. Bizonyos betegeknél, akiknél hosszabb AHRE/ szubklinikus PF jelentkezik ( $\geq 24$ óra) és a stroke-rizikó magas, OAC bevezetése megfontolható. A rendelkezésre álló tudományos adatok arra utalnak, hogy az AHRE/szubklinikus PF-hez társuló abszolút stroke-rizikó alacsonyabb, mint klinikai PF esetén és az AHRE/szubklinikus PF inkább egy stroke-markerként, mint rizikófaktorként értékelendő.

\section{Következtetések}

Az új 2020-as ESC PF kezelését taglaló guideline egyértelműen a PF holisztikus kezelését hangsúlyozza. Az utóbbi évek kutatásai alapján egyértelművé vált, hogy egy komplex betegséggel állunk szemben, amely- nek kezeléséhez a multidiszciplináris szemlélet elengedhetetlen.

\section{Nyilatkozat}

A szerzők kijelentik, hogy az összefoglaló közlemény megírásával kapcsolatban nem áll fenn velük szemben pénzügyi vagy egyéb lényeges összeütközés, összeférhetetlenségi ok, amely befolyásolhatja a közleményben bemutatott eredményeket, az abból levont következtetéseket vagy azok értelmezését.

\section{Irodalom}

1. Hindricks G, Potpara T, Dagres N, et al. 2020 ESC Guidelines for the diagnosis and management of atrial fibrillation developed in collaboration with the European Association for Cardio-Thoracic Surgery (EACTS): The Task Force for the diagnosis and management of atrial fibrillation of the European Society of Cardiology (ESC) Developed with the special contribution of the European Heart Rhythm Association (EHRA) of the ESC. Eur Heart J 2021; 42(5): 373-498. https://doi.org/10.1093/eurheartj/ehaa612 